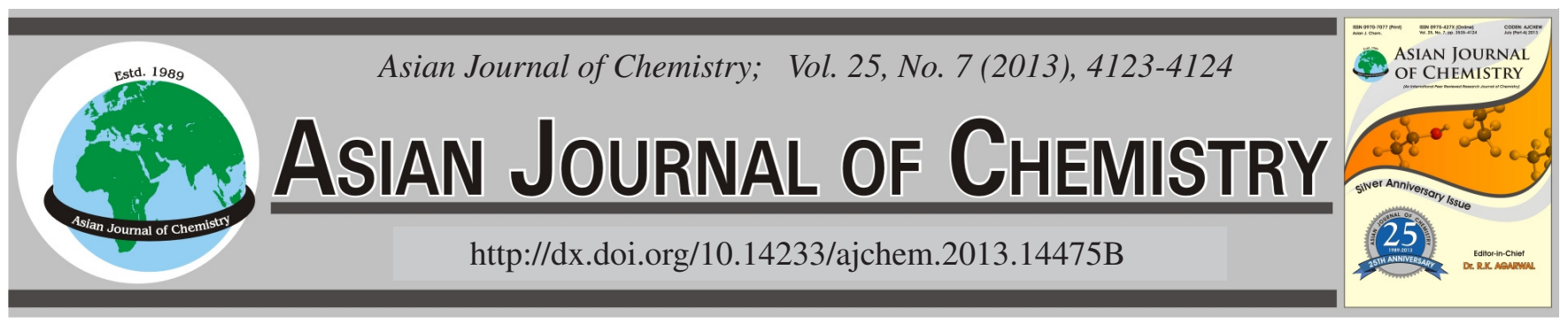

NOTE

\title{
Spectrophotometric Determination of Magnesium in Tea
}

\section{XIAO-Dong Li $^{1, *}$ and QING-Zhou ZhaI ${ }^{2}$}

${ }^{1}$ Key Laboratory of Songliao Aquatic Environment, Ministry of Education, Jilin Architectural and Civil Engineering Institute, 5088 Xincheng Street, Changchun 130118, Jilin Province, P.R. China

${ }^{2}$ Research Center for Nanotechnology, South Campus, Changchun University of Science and Technology, 7186 Weixing Road, Changchun 130022, P.R. China

*Corresponding author: E-mail: dxiaoli@163.com

The optimum conditions for the spectrophotometric determination of $\mathrm{Mg}$ (II) using chlorophosphonazo-III (CPA-III) as chromogenic agent. The present method has been successfully applied to the determination of magnesium in tea samples. In a medium of $\mathrm{pH}^{9.5 \mathrm{NH}_{3-}}$ $\mathrm{NH}_{4} \mathrm{Cl}$ the maximum absorption peak of $\mathrm{Mg}(\mathrm{II})-(\mathrm{CPA}-\mathrm{III})$ is at $676 \mathrm{~nm}$, at which the apparent molar absorptivity of the method is $1.77 \times$ $10^{4} \mathrm{~L} \mathrm{~mol}^{-1} \mathrm{~cm}^{-1}$ and Beer's law is obeyed over the range of $0-0.48 \mu \mathrm{g} / \mathrm{mL}$. Its regression equation is: $\mathrm{A}=0.9519 \mathrm{C}(\mu \mathrm{g} / \mathrm{mL})+0.0101$, with a correlated coefficient of 0.9990 . The detection limit of method is $8.92 \mathrm{ng} / \mathrm{mL}$.

Key Words: Magnesium, Chlorophosphonazo-III, Spectrophotometry, Tea.

Magnesium is one of the elements whose contents are the most in a human body. Daily requirement amount of human for magnesium is about 300-700 mg. Magnesium participates in the synthesis of protein and of nucleic acid. The metabolism of more than 300 kinds of enzymes, the conductibility constringency of neuromuscular and nervus centralis system activities are all adjusted by magnesium ions and magnesium almost participates in all metabolism processes ${ }^{1}$. The lack of magnesium consequentially brings the harm of human body health, resulting in the occurance of heart disease and diabetes, etc. However, if the magnesium content in human body is too high, it results in the damage of human health ${ }^{2}$. Human being can absorb the magnesium in tea by drinking tea. Therefore, the determination of magnesium contents in tea have an important value and scientific instruction significance for knowing the intake amount of magnesium component of tea leaf.

The methods for the determination of magnesium have mass spectrometry, atomic absorption spectrometry, fluorescent method, etc., but some deficiencies exist for the above methods such as instrumentation costliness, operation inconvenience, etc. ${ }^{2}$. Spectrophotometry has the characteristics of low cost instrumentation, operation simplicity and determination sensitivity highness, etc., it has the advantages of higher practical value. Although some spectrophotometric methods 4-(2-hydorxyl-4-nitrophenylazo)-1-phenyl-3-methyl-pyrazolone ${ }^{3}$, chlorophosphonazo- $\mathrm{I}^{4}, 4$-methylarsenazo- $\mathrm{I}^{5}$, etc. for the determination of magnesium have been proposed, the selectivity of method are still not ideal. Exploration of new spectrophotometric methods for the determination of magnesium is still needed. Chlorophosphonazo-III ${ }^{6}$ (CPA-III) is a rare earths chromogenic agent. The present article studied the colour reaction of the reagent with magnesium(II) and was successfully applied to the determination of magnesium in tea leaf samples.

A 722 spectrophotometer (Shanghai Prism Light Technology Corporation, Ltd., China) with $1 \mathrm{~cm}$ cells was employed for all absorbance measurements. A standard stock solution containing $1 \mathrm{mg} / \mathrm{mL}$ of $\mathrm{Mg}^{2+}$ was prepared by dissolving $0.1658 \mathrm{~g}$ magnesium oxide in $1 \mathrm{~mL}$ of concentrated hydrochloric acid and then the content was diluted to $100 \mathrm{~mL}$. The working solution $(2 \mu \mathrm{g} / \mathrm{mL})$ was prepared by the suitable dilution of the stock solution. $0.5 \mathrm{~g} / \mathrm{L}$ of chlorophosphonazoIII (CPA-III, Shanghai Jinsheng Chemical Corporation, Ltd., China) solution was used as chromogenic agent solution. $\mathrm{pH}$ $9.5 \mathrm{NH}_{3}-\mathrm{NH}_{4} \mathrm{Cl}$ buffer solution was applied for controlling the acidity of colour reaction.

$6 \mu \mathrm{g}$ of magnesium(II) working solution was taken and placed in $25 \mathrm{~mL}$ calibrated flask, $1.0 \mathrm{~mL}$ of $0.5 \mathrm{mg} / \mathrm{mL} \mathrm{CPA-}$ III solution and $1.0 \mathrm{~mL}$ of $\mathrm{pH} 9.5 \mathrm{NH}_{3}-\mathrm{NH}_{4} \mathrm{Cl}$ buffer solution were added in turn. The above solution was diluted with water to the mark and shaken well. After $20 \mathrm{~min}$, the absorbance 
was determined at $676 \mathrm{~nm}$ with $1 \mathrm{~cm}$ cells using reagent blank as reference.

Absorption spectra: The experimental results showed (Fig. 1) that the maximum absorption wavelength of reagent blank against water is located at $590 \mathrm{~nm}$ and a shoulder peak exists at $650 \mathrm{~nm}$. The maximum absorption wavelength of complex against reagent blank is located at $676 \mathrm{~nm}$ and a shoulder peak exists at $620 \mathrm{~nm}$. The contrast is $\Delta \lambda=86 \mathrm{~nm}$. The present study selected the determination wavelength to be $676 \mathrm{~nm}$.

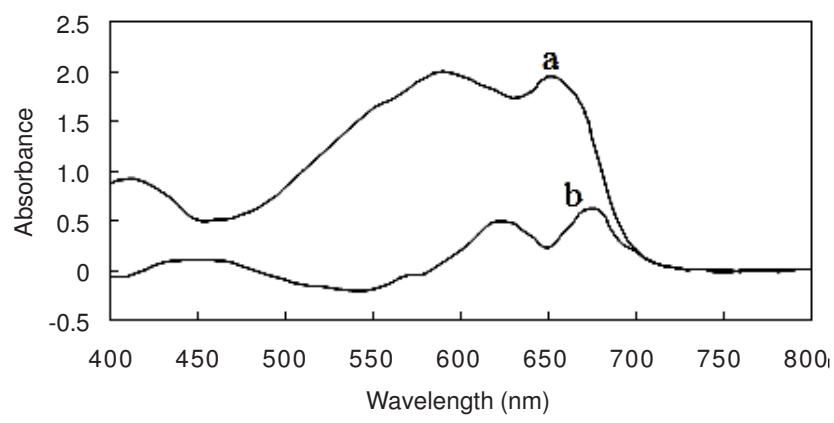

Fig. 1. Absorption spectra: (a) Reagent blank (against water); (b) complex (against reagent blank); $\left[\mathrm{Mg}^{2+}\right]=8.23 \times 10^{-5} \mathrm{~mol} / \mathrm{L} ;[\mathrm{CPA}-\mathrm{III}]=$ $6.60 \times 10^{-4} \mathrm{~mol} / \mathrm{L} ; \mathrm{pH} 9.5$

Effects of acidity: The experimental results showed that the absorbance of complex increased as $\mathrm{pH}$ increased over the range of 8.0-9.5. The absorbance of complex decreased as $\mathrm{pH}$ increased within $\mathrm{pH}$ 9.5-11.0. At $\mathrm{pH} 9.5$, the absorbance was a maximum. In this experiment, $\mathrm{pH} 9.5$ was selected. The amount effect of buffer solution was not great on the system. Within 0.2-2.0 mL, the absorbance was basically unchangeable. $1.0 \mathrm{~mL}$ was used.

Effect of the amount of CPA-III: The experimental results showed that within $0-1.0 \mathrm{~mL}$ of the added amount of CPA-III, the absorbance gradually increased. At $1.0 \mathrm{~mL}$, the absorbance achieved a maximum. Within $1.0-2.0 \mathrm{~mL}$, the absorbance gradually minished with increase in the amount of CPA-III. In this work, the CPA-III amount selected was 1.0 $\mathrm{mL}$ and at this time, the CPA-III concentration was $6.60 \times 10^{-4}$ $\mathrm{mol} / \mathrm{L}$.

Effect of surfactant: According to the standard procedure, the effect experiments of cetyltrimethylammonium bromide, Tween-80 and sodium lauryl sulfate were respectively made. The results showed that the added above three kinds of different type surfactants made the sensitivity of colour reaction reduce.

Complex stability and composition: The experimental results showed that CPA-III and $\mathrm{Mg}$ (II) produced a complex within $20 \mathrm{~min}$ and the complex could be stable for $1.5 \mathrm{~h}$. Using molar ratio method and equimolar continuous variation method, the molar composition ratio of $\mathrm{Mg}$ (II) and the chromogenic agent in the complex was determined to be $1: 1$.

Working curve: The experimental results showed that between a range of $0-0.48 \mu \mathrm{g} / \mathrm{mL}$ of $\mathrm{Mg}$ (II) and the absorbance a good linear relationship is presented and its regression equation is: $\mathrm{A}=0.9519 \mathrm{C}(\mu \mathrm{g} / \mathrm{mL})+0.0101$, with a correlation coefficient of $\mathrm{r}=0.9990$. At $676 \mathrm{~nm}$, the apparent molar absorptivity of method is $1.77 \times 10^{4} \mathrm{~L} \cdot \mathrm{mol}^{-1} \cdot \mathrm{cm}^{-1}$. For eleven parallel determinations of $0.30 \mu \mathrm{g} / \mathrm{mL} \mathrm{Mg}(\mathrm{II})$, the relative standard deviation of method was calculated to be $1.19 \%$. The detection limit of method was calculated to be $8.92 \mathrm{ng} / \mathrm{mL}$ according to $3 \mathrm{~S} / \mathrm{K}$ method ( $\mathrm{S}$ is the standard deviation of eleven blank experiments, $\mathrm{K}$ is the slope of regression equation).

Selectivity of method: Under the optimum experimental conditions, the experiments of selectivity of the method were carried out. When $0.24 \mu \mathrm{g} / \mathrm{mL}$ of $\mathrm{Mg}$ (II) was determined and the relative error was controlled within $\pm 5 \%$, the following amounts $(\mathrm{m} / \mathrm{m})$ of co-existing ions did not cause effects: $\mathrm{NO}_{3}{ }^{-}$ (300); citric acid (250); salicylic acid, glucose, ascorbic acid (200); $\mathrm{F}^{-}, \mathrm{SiO}_{3}{ }^{2-}, \mathrm{SO}_{4}{ }^{2-}(100) ; \mathrm{Br}^{-}, \mathrm{NO}_{2}{ }^{-}$, phenylalanine, bovine serum albumin (50); cysteine (30); $\mathrm{MoO}_{4}{ }^{2-}$, glutamic acid, lysine (20); $\mathrm{Zn}^{2+}(15) ; \mathrm{I}^{-}, \mathrm{PO}_{4}^{3-}$, leucine (10); $\mathrm{S}_{2} \mathrm{O}_{7}{ }^{2-}(8) ; \mathrm{BrO}_{3}^{-}$, $\mathrm{Ag}^{+}, \mathrm{Fe}^{2+}, \mathrm{Co}^{2+}, \mathrm{Fe}^{3+}$, bovine hemoglobin (5); $\mathrm{Al}^{3+}\left(5,50^{\mathrm{a}}\right)$, $\mathrm{MnO}_{4}^{-}, \mathrm{Pb}^{2+}(3) ; \mathrm{VO}_{3}^{-}, \mathrm{Li}^{+}, \mathrm{Ni}^{2+}, \mathrm{Cu}^{2+}, \mathrm{Ba}^{2+}, \mathrm{Bi}^{3+}, \mathrm{Cr}(\mathrm{III})$ (2); $\mathrm{CH}_{3} \mathrm{COO}^{-}, \mathrm{Cr}^{3+}(1) ; \mathrm{Mn}^{2+}(0.2) ; \mathrm{Ca}^{2+}\left(0.1,1^{\mathrm{a}}\right)(\mathrm{a}: 2.0 \mathrm{~mL}$ of 0.5 $\mathrm{mg} / \mathrm{mL}$ EDTA-Na $\mathrm{Na}_{2}$ were added).

Sample analysis: $2.5 \mathrm{~g}$ of tea leaf were accurately weighed, firstly placed in an electronic oven for carbonization and then incinerated for $5 \mathrm{~h}$ at $550{ }^{\circ} \mathrm{C} .2 \mathrm{~mL}$ of concentrated nitric acid and $4 \mathrm{~mL}$ of concentrated hydrogen peroxide were added, the content was heated at low temperature and evaporated to near dryness. After cooling, it was diluted to $50 \mathrm{~mL}$ with water, $5 \mathrm{~mL}$ was taken and diluted to $50 \mathrm{~mL}$ by water. A suitable amount of the solution was taken and magnesium was determined according to the standard procedure. Magnesium content in the sample was calculated and the determined results are seen in Table-1. The recovery of method was between 97.1$100.1 \%$.

TABLE-1

ANALYTICAL RESULTS OF SAMPLE

\begin{tabular}{ccccc}
\hline Sample & $\begin{array}{c}\text { Average value } \\
\text { determined by } \\
\text { the present } \\
\text { method } \\
(\mathrm{n}=7, \mathrm{mg} / \mathrm{g})\end{array}$ & $\begin{array}{c}\text { Relative } \\
\text { standard } \\
\text { deviation } \\
(\%)\end{array}$ & $\begin{array}{c}\text { Recovery } \\
(\%)\end{array}$ & $\begin{array}{c}\text { Atomic } \\
\text { absorption } \\
\text { spectrometric } \\
\text { contrast method } \\
(\mathrm{mg} / \mathrm{g})\end{array}$ \\
\hline No.1 & 1.34 & 1.03 & 99.13 & 1.34 \\
No.2 & 1.13 & 1.33 & 100.3 & 1.10 \\
\hline
\end{tabular}

\section{Conclusion}

The study reported the optimum conditions for the spectrophotometric determination of $\mathrm{Mg}$ (II) using chlorophosphonazoIII (CPA-III). At the maximum absorption wavelength 676 $\mathrm{nm}, \varepsilon_{676 \mathrm{~nm}}=1.77 \times 10^{4} \mathrm{~L} \cdot \mathrm{mol}^{-1} \cdot \mathrm{cm}^{-1}$, Beer's law is obeyed over the range of $0-0.48 \mu \mathrm{g} / \mathrm{mL}$ for $\mathrm{Mg}$ (II) amount and its regression equation is : $\mathrm{A}=0.9519 \mathrm{C}(\mu \mathrm{g} / \mathrm{mL})+0.0101$. The detection limit of method is $8.92 \mathrm{ng} / \mathrm{mL}$.

\section{REFERENCES}

1. T. Xu and C.B. He, Stud. Trace Elements Health, 21, 60 (2004).

2. X.W. and Y.Z. Wen, Stud. Trace Elements Health, 25, 58 (2008).

3. B. Yang, F. Liu, J. Pu, X.F. Li and J.Y. Yin, Chin. J. Spectr. Lab., 21, 191 (2004).

4. H.Y. Xu and C.H. Li, Guangxi J. Light Ind., 14, 43 (2007).

5. Z.Q. Ji and J.F. Huang, Metal. Anal., 13, 50 (1993).

6. J.M. Pan, Z.J. Li, Q.Y. Zhang and G.Z. Fang, New Chromogenic Reagents and Their Application in Spectrophotometry, Beijing : Chemical Industry Press, p. 35 (2003). 